\title{
Herd Behaviour and Gold Investment: A Perceptual Study of Retail Investors
}

\author{
*** Dr. B.S. Hundal,** Dr. Saurabh Grover, *Jasleen Kaur Bhatia \\ ***Associate Professor, Department of Commerce and Business Management, Guru Nanak Dev University, Amritsar. \\ ** Assistant Professor, Department of Commerce and Business Management, Guru Nanak Dev University, Amritsar. \\ *Research Scholar, Department of Commerce and Business Management, Guru Nanak Dev University, Amritsar.
}

\begin{abstract}
Needs, Benefits, Fund Allocation Patterns and Resources may vary among investors but the motive is to earn beneficial level of return. The level of return may vary but an investor expects some added advantage over the blocked money. Specifically in Asia and the Middle East, gold investments and gold jewelry are regarded as financial or semi-financial assets. Consumers have become aware of price movements and very sensitive to them. Unlike paper currency, coins or other assets, gold has maintained its value throughout the ages. People see gold as a way to pass on and preserve their wealth from one generation to the next. The perceptions of an investor differ with respect to alternative investment avenues, assets and segments present in the market. This study includes 183 respondents from different cities of Punjab. This paper is an attempt to study the factors influencing purchase behavior of retail investors towards gold with the help of Factor Analysis.
\end{abstract}

Keywords: Individual, Investment, Return, Perceptions, Gold.

\section{Introduction}

Until the end of last century, Middle class Indians paid a little attention on managing personal finance during their working life span and consulted their peers or advisors about some deposit schemes with banks or post office or companies only at the time of retirement or at the crisis time (Das, 2012).

Now when the growth of the capital market has substantially increased during the past few years, the investor population has also boomed in India. Each investor holds different objective that needs to be accomplished depending on demographic and psychological needs of an individual. The relevance of correct advice at the right time is being appreciated nowadays and an investor is trying to become the manager of their personal finance (Ramanujam and Devi, 2012). Research indicates that investors' behavior will be affected by personality traits, interpretation of information, responses of sentiments, return and risk (Maital et al. , 1986).

This has lead to the need of understanding the perceptions of investors in terms of their investments; strategies and expectations etc. (Vanjeko, 2010). Infinite investors are available in the markets who have the money but more or less knowledge of investment. Less knowledgeable investors usually encounter one common phenomenon of Herd behavior which further leads to extreme market results. (Scharfstein and Stein, 1990).

Giving regard to all the above views, intensive research has been carried on the prominent investment avenues. Dempster (2006) recognized India as the world's foremost gold consumer in tonnage terms for many years to come in the World Gold Council Report, 2006. Gold has three crucial attributes that, apparently, set it apart from other commodities: firstly, certainly gold is homogeneous; secondly, gold is indestructible and fungible; and thirdly, the inventory of above ground stocks is astronomically large relative to changes in flow demand (Lawrence 2003). Gold is also viewed as a secure and easily accessible savings vehicle by the rural community, where around 70\% of the population lives (Dempster, 2006).

Gold has three characteristics which lure Indians. First, it has held value for so long. Second, it is portable, and a useful hedge against adversity. It is held for distress situations and is easily encashable (Aggarwal and Lucey, 2007). Third, equity has not been a fail-safe deliverer of value for most ordinary Indians. For those who seek safety of capital, gold is the alternative to fixed deposits (Jagannathan, 2013; Singh and Nadda, 2013; Ghosh et.al., 2004).

\section{Review of Literature}

Investors are of varied personality types and have behavioral biases which impact the way they process the information for investment decisions. Concerning this matter, Mittal (2008) observed that investors tend to act 'normal' rather than 'rational' while making their investment choices suggested four dominant investment personalities (Casual, Technical, Informed and Cautious). Gender is a significant factor that influences the gold buying behavior and this was proved by the research of Sujatha and Kumaresan (2013) and Kaynak and Kara (2002) who also recommended that lifestyle patterns affect individuals to determine their investment behavior. 
Mukhi (1989) studied the consumer behavior towards investment and found that national Savings Scheme is one of the most eminent tax savings instruments in India as it is user friendly. Similarly, Pati and Shome (2011) in their research article suggested that households prefer the safer channels of investments rather than switching over to high yielding but risky channels of savings. Udompaibumsuk (2003) compared three monetary savings methods and concluded that general fixed income fund was more suitable than other types of savings because of lower risk per unit of return rate. Further Das (2011), Devi (2012), Das et al. (2008), Bishnoi (2013) studied investment patterns of rural and Semi-Urban households and revealed that insurance products are the most preferred investment avenue of the households at large. Studies conducted by Palanivelu and Chandrakumar (2013); Bishnoi (2013); Ramanujam and Devi (2012) concluded that people prefer to invest in insurance and banking products due to the high risk involved in other investment avenues.

On a global level, Gold is considered as a safe haven and this finding was supported by the studies conducted by Forrest et.al (2005), Baur and Lucey (2010) and Surya and Anwar (2012). Lutter (2008) conceptualized the fact that gold is a long term stable backbone of any Investment Portfolio. To further strengthen the fact, Singh and Nadda (2013) carried on a comparative study of risk and return associated with the data collected from official websites of National Stock Exchange and Multi Commodity Exchange for the period ranging from 2005-2006 to 2012-2013 and revealed that risk involved in Gold is less than one third of the risk involved in Stock Investment.

There are several considerations in the mind of an individual before stepping into an investment and to study the notion, Arulmurugan et. al (2013) studied the investment behavior of professors towards Gold Investment in Tamil Nadu State, India and found five factors which included Risk Management, Ideal Time for Investment, Conventional Value, Investment Tool and Future Prospects.

(Insert Table 1)

\section{Need of the Study}

A number of studies have been conducted on various individual dimensions of gold as an investment (Arulmurugan et al. (2013); Baur and Lucey (2010); Lutter. (2008); Ghosh et al. (2004); Sujatha and Kumaresan (2013); Anli (2011) etc.) but they have ignored the preferred attributes of gold which make it the real choice of retail investors.

The perception about gold in India has evolved from the days when its main utility was just to adorn and act as a status symbol and the emotional investment in the metal was so huge that parting with it seemed unthinkable (Economic Times, 2011). An increasing number of Indians are realizing that gold deserves a place not just in the chest of cabinet at home or the bank locker, but also in their investment portfolio.

Our macroeconomic forecast to 2020 shows India is poised for a very strong period of economic growth and this has significant, positive implications for all forms of gold purchasing in India (World Gold Council, 2011). With 50 per cent of the Indian population, below 25 years and approximately 150 million weddings anticipated over the next decade, which will drive gold consumption (Anli, 2010); it becomes essential to understand the purchase behavior of this population.

No single study has attempted to understand the perceptions of retail investors towards purchase of gold but our study not only focuses on exploring the perceptions regarding purchase of gold but also the factors effecting gold purchase. It will be helpful for various investment portfolio advisers, marketers, foreign investors, retail business chains and accordingly they can form different strategies to target Indian market where individuals seek a combination of profits, safety and recognition in their investments.

\section{Objective of Study}

To study the perception of retail investors towards purchase of gold.

\section{Database and Research Methodology}

Tinsley and Tinsley (1987) suggest a ratio of about 5 to 10 subjects per item up to about 300 subjects. Here we have 33 variables/items, so proportionate ratio of subjects has been taken. The present study is mainly based on primary data collected from around 183 respondents from Punjab Region.

These respondents were interviewed through a pretested, well structured questionnaire which was administered personally. Convenient and judgmental sampling method has been used keeping in view the socio economic characteristics. The sampling size includes both male and female users from different occupation, age, and income groups. The data collected was classified, tabulated and processed mainly to identify the factors affecting the perception of retail investors. The survey was conducted during the period of June 2013 to October 2013. The statements were measured on the 5-point Likert scale where 5, indicates strongly agree and 1 indicates, strongly disagree. Factor Analysis was used to find out the perception of respondents towards purchase of Gold as Investment Avenue. The data is analyzed by using SPSS 17. 
Factor Analysis- Factor analysis is a set of techniques which, by analyzing correlations between variables, reduces their number into fewer factors which explains much of the original data, more economically (Nargundkar 2010). Explanatory factor analysis is used to identify the underlying constructs and investigate relationships among the key survey interval-scaled questions regarding perception towards purchase of gold (Adamowicz et al., 1998 and Kahn, 2006).

Internal consistency should be determined before a test can be employed for research or examination purposes to ensure validity. In addition, reliability estimates show the amount of measurement error in a test (Tavakol and Dennick, 2011). To test the suitability of data, reliability test has been conducted and value of Cronbach's alpha comes out to be .847 which is significant for 33 variables used in the survey (Brown, 2002).

The following steps have been conducted to analyze the data

1. The correlation matrix is computed and examined. It reveals that there are enough correlations to go ahead with factor analysis.

2. The Kaiser-Meyer-Olkin measure of sampling adequacy is an index used to examine the appropriateness of factor analysis where high Values (between 0.5 and 1.0) indicate factor analysis is appropriate (Malhotra 2005). It is computed which is found to be .670 and indicates that the sample is good enough for sampling.

3. The overall significance of correlation matrices is tested with Bartlett Test of Sphericity (approx chi square $=$ 2433.946 and significant at .000) provided as well as support for validity of the factor analysis of the data set.

Hence, all these three standards indicate that the data is suitable for factor analysis.

Rotation Method: Orthogonal rotation with Varimax was applied. Orthogonal Rotation Method corresponds with factors that are statistically independent of one another (i.e., uncorrelated). Such factors are described as orthogonal (Abdi, 2003).

Principal components analysis yields one or more composite variables that capture much of the information originally contained in a larger set of items where the components are defined as weighted sums of the original items and principal components are linear transformations of the original variables. They are grounded in actual data and are derived from the actual items. It is merely a reorganization of the information in the actual items (DeVellis, 2011).

Criteria for the Significance of Factor Loadings- In interpreting factors, a decision must be made regarding which factor loadings are worth considering. A factor loading represents the correlation between an original variable and its factor. The criterion given by Hair et al. (1995), where factor loading based on sample size is taken as the basis for decision about significant factor loading, was adopted. For this sample of 183 respondents, a factor loading of .5 and above has been considered significant and chosen from Table 2.

\section{(Insert Table 2)}

According to the Eigen value rule (Kaiser, 1960) asserts those factors with Eigen values less than 1.0 (and, thus, containing less information than the average item) should not be retained. There are ten factors having Eigen values exceeding one in this study. An Eigen value represents the amount of information captured by a factor (DeVellis, 2011).

As represented in Table 2, Eigen Values for Factors 1 to 10 are 5.981, 3.236, 2.385, 2.271, 1.842, $1.579,1.300,1.197,1.080$ and 1.063. The percentage of variance explained by individual factors is shown in the penultimate row of the table. The percentage of variance explained by factors 1 to 10 are $18.124 \%, 9.805 \%$, $7.227 \%, 6.881 \%, 5.582 \%, 4.785 \%, 3.939 \%, 3.629 \%, 3.273 \%$ and $3.222 \%$. The percentage of total variance is used as an index to determine how well the total factor solution accounts for what the variables together represent (Pavleen, 2006). The index for present solution accounts for $66.956 \%$ of the total variation. It is significant figure and we lost only $33.044 \%$ of the information content in the study.

The names of the factors, the variance explained and factor loadings are summarized in table 3 .

$$
\text { (Insert Table 3) }
$$

\section{Discussion}

Consistent with Colin Lawrence (2003), the findings confirm that gold appears to be independent of cycles in contrast to other commodities, making it worth considering as a good portfolio diversifier because the results indicate Gold has always given high returns over a long period, that's why it's preferable irrespective of other factors according to Factor 1 as shown in the table 3 . The same concept has been confirmed by the research work of Jaana Lisette Lutter (2008) where the study indicated that the main motive to investing comes 
from the factor that more money is left over from other expenses and one wants to preserve it's worth for the future in the situation where inflation is growing.

It is also observed in this study Gold is considered as one of the most liquid assets, since it can be easily converted back to cash and hence the resale value of gold is quite high compared to other types of asset. The other important consideration noted in the reason for buying gold is that gold has a very high traditional value in India. This includes buying gold during festivals, marriages, etc (V.Sujatha \& S.Kumaresan, 2013). There are various festivals in India during which buying gold is considered auspicious. Gold is considered to be a safe asset due to which people prefer investing and saving in the form of gold.

The factor of safety has also been considerably weighted by the respondents in the study. This part of the study is also consistent with the results of the research conducted by Forrest Capie, Terence C. Mills, Geoffrey Wood (2005); Ghosh, D et al. (2004) where the findings revealed that that gold has served as a hedge against fluctuation in the foreign exchange value of the dollar, but that it has done so to a degree that seems highly dependent on somewhat unpredictable political attitudes and events. The Studies of D.G. Baur, T.K. McDermott (2010); Baur, D.G., Lucey, B.M. (2010) also revealed that gold is a strong safe haven for most major developed world stock markets and Gold thus has the potential to act as a stabilizing force for the global financial system by reducing losses when it is most needed.

The fact that gold can be bought in as small a quantity as $0.5 \mathrm{gm}$ (approx. Rs.2900) enabling consumer to invest whatever surplus they might have on hand and increasing prices only add to the attractive returns. The similar results were shown in the study conducted by P.Arulmurugan et al. where they exhibited 5 main factors influencing the investment behaviour of professors towards gold (Future prospect, Ideal Time for Investment, Investment Tool, Conventional Value and Risk Management).

\section{Conclusion}

The perception of retail investors towards purchase of gold in the present scenario has been worked out with the help of questionnaire in this study. The results of factor analysis revealed that variables like profitability, tax aversion, future prospect, time value of money etc. motivates a retail investor to purchase gold as an investment.The purpose for buying gold has clearly come out through the survey. Despite hike in taxes and depreciating rupee, unless the consumers get suitable alternatives which meet their respective needs, people don't want to shift away from gold, rather they are treating gold as a safety buffer. Another major advantage for gold being preferred is that it has multiple characteristics which very few other assets have - high liquidity: both in terms of ease of en-cashing it or availing a gold loan from bank but also the resale value (very small deduction while re-selling); conventional value and cultural values it holds for the consumers.

\section{References}

[1]. Abdi H (2003), "Factor rotations in factor analyses", Encyclopedia for Research Methods for the Social Sciences, Sage: Thousand Oaks, CA: 792-795

[2]. Adamowicz W, Louviere J and Swait J. (1998), Introduction to attribute-based stated choice methods. NOAA-National Oceanic Atmospheric Administration, Washington, USA.

[3]. Anli S (2011), A Review on Gold Quest in the Investment Portfolio by Indian Investors. International Journal of Research in Management \& Technology (IJRMT), 1(2), Available at SSRN: http://ssrn.com/abstract=2336590.

[4]. Arulmurugan P et al. (2013), A Study On Investment Behavior of Professors Towards Gold with Special Reference to Tamil Nadu State. International Journal of Scientific Research: 2(2), ISSN 2277-8179.

[5]. Baur DG, Lucey BM (2010), Is gold a hedge or a safe haven? An analysis of stocks bonds and gold. The Financial Review (45): 217-229.

[6]. Baur DG, Thomas K. McDermott C (2010), Is gold a safe haven? International evidence. Journal of Banking \& Finance (34): 1886-1898.

[7]. Bishnoi S (2013), An Empirical Study on Investors' Behaviour in National Capital Region (NCR). International Journal on Global Business Management and Research, 14.

[8]. Brown JD (2002), Statistics Corner. Questions and answers about language testing statistics, The Cronbach alpha reliability estimate, Shiken: JALT Testing \& Evaluation, SIG Newsletter. 6 (1): 17-18.

[9]. Capie F, Mills TC and Wood G (2005), Gold as a hedge against the dollar. Journal of International Financial Markets, Institutions and Money (15): 343-352.

[10]. Das SK (2012), Investment Habits among the Households. Asian Journal of Research in Banking and Finance 2(6), ISSN 22497323.

[11]. Das B, Mohanty S and Shil NC (2008), Categorizing consumers' buying behavior: a factor analysis in consumer durable market. International Journal of Business and Management, 3(9): 147

[12]. Dempster N (2006), The Role of Gold in India. World Gold Council Report.

[13]. DeVellis Robert F (2011), Scale Development: Theory and Applications, Sage Publications.

[14]. Devi C (2012), A Study on Impact of Socio-Economic Profile on Investment Pattern of Salaried and Business People in Coimbatore City. International Journal of Management \& Information Technology, 2(1): 67-77.

[15]. Ghosh D et al. (2004), Gold as an inflation hedge? Studies in Economics and Finance, 22 (1): 1-25. ISSN 1086-7376.

[16]. Hair JF et al. (1995), Multivariate Data Analysis, 4th Edition, Prentice Hall, New Jersey.

[17]. Kahn JH (2006), Factor Analysis in Counseling Psychology Research, Training, and Practice Principles, Advances, and Applications. The Counseling Psychologist, 34(5): 684-718. 
[18]. Kaynak E and Kara A (2002), Consumer perceptions of foreign products: an analysis of product-country images and ethnocentrism. European Journal of Marketing, 36(7/8): 928-949, DOI: 10.1108/03090560210430881.

[19]. Lawrence Colin. (2003), Why is gold different from other assets? An empirical investigation. World gold council.

[20]. Lutter JL (2008), Consumer Behavior during Investment Gold Purchase in comparison to other Investment Instruments, PhD Thesis, Tallinn University, Baltic Film and Media School, Tallinn 2008

[21]. Maital RF and Simon J (1986), What do people bring to the stock market (beside money)? The Economic Psychology of Stock Market Behavior, B, Greenwich, Connecticut, JAI Press Inc : 273-307.

[22]. Malhotra N K (2005), Marketing Research: An Applied Orientation, Pearson Edu. (India Branch), New Delhi.

[23]. Mittal M (2008), Personality Type and Investment choice: An empirical Study.

[24]. Mukhi MD (1989), NSCs: A Saving Grace, Business World(December 1989): 107-120.

[25]. Mulyadi MS and Anwar Y (2012), Gold vs. Stock Investment: An Econometric Analysis. International Journal of Development and Sustainability, 1(1): 1-7.

[26]. Napompech K. et al. (2010), Factors Influencing Gold Consumption for Savings and Investments by People in the Bangkok Metropolitan Area. International Journal of Arts and Sciences, 3(7): 508-520.

[27]. Nargundkar R (2010), Marketing Research: Text and Cases, Tata McGraw-Hill Publishing Company, New Delhi.

[28]. Palanivelu V R. and Chandrakumar K. (Eds) (2013), Proceedings from The 2013 IBEA: International Conference on Business, Economics, and Accounting, A. Study on Preferred Investment Avenues among Salaried Peoples with Reference to Namakkal Taluk, Tamil Nadu, India.

[29]. Pati A.P. \& Shome D (2011), Do households Still Prefer Bank Deposits? An Analysis of Shift in Savings and Savings Determinants.", The IUP Journal of Management, 10(1): 46-59.

[30]. Pavleen (2006), Consumer Decision Making, Deep and Deep Publications, 140.

[31]. Quisumbirg AR (2011), Do Men and Women accumulate assets in different ways, Evidence from Rural Bangladesh", IFPRI Discussion Papers 1096, International Food Policy Research Institute.

[32]. Raj Aggarwal, Brian M. Lucey (2007), Psychological barriers in gold prices. Review of Financial Economics (16): 217-230.

[33]. Ramanujam V and Chitra DK (2012), A Study on Impact of Socio -Economic Profile on Investment Pattern of Salaried \& Business People in Coimbatore City. International Journal of Management \& Information Technology, 2(1).

[34]. Scharfstein DS and Stein JC (1990), Herd Behavior and Investment. The American Economic Review, 80(3): 465-479, Available at: http://www.jstor.org/stable/2006678.

[35]. Singh B and Nadda JB (2013), Gold vs. Stock Market: A Comparative Study of Risk and Return. International Journal of Management \& Research (IJBMR), ISSN 2249-6920, 2(3): 103-110.

[36]. Sujatha V and Kumaresan S (2013), Influence of Lifestyle Perception on Gold Purchase Decisions. Global Research Analysis, 2(7), ISSN 2277-8160.

[37]. Tavakol M and Dennick R (2011), Making sense of Cronbach's alpha. International Journal of Medical Education (2): 53-55, ISSN: 2042-6372, DOI: 10.5116/ijme.4dfb.8dfd.

[38]. Udompaibunsuk W (2003), Comparison of three money saving methods- gold bar holdings, investment in general fixed income fund, and fixed deposit investment . Bangkok. Independent Study, Kasetsart University. Bangkok.

[39]. Vanjenko R (2003), Investors Demographics and risk bearing capacity. Finance India, 17(2): 565-576.

[40]. World Gold Council (2011), Available at: http://articles.economictimes.indiatimes.com/2011-04-05/news/29384334_1_gold-etfsindian-gold-demand-gold-rush

[41]. World Gold Council (2011), Gold demand in India to continue to grow in the next decade, strengthening its position as the heart of the global gold market. Available at: http://www.gold.org/media/press_releases/archive/2011/03/gold_demand_in_india/

Table 1: Review of Literature

\begin{tabular}{|c|c|c|c|c|}
\hline \multicolumn{5}{|c|}{ REVIEW OF LITERATURE } \\
\hline S.No. & Title & Author & Year & Findings \\
\hline 1 & NSCs: A Saving Grace & M.D.Mukhi & 1989 & $\begin{array}{l}\text { Extremely convenient to buy NSCs and pledge } \\
\text { these to the securities. }\end{array}$ \\
\hline 2 & Gold as a hedge against the dollar & Forrest Capie et al. & 2005 & $\begin{array}{l}\text { Although gold has served as a hedge against } \\
\text { fluctuations in the foreign exchange value of the } \\
\text { dollar, it has only done so to a degree that seems } \\
\text { highly dependent on unpredictable political } \\
\text { happenings and events. }\end{array}$ \\
\hline 3 & $\begin{array}{l}\text { The Role of Gold in India. World } \\
\text { Gold Council Report. }\end{array}$ & Natalie Dempster & 2006 & $\begin{array}{l}\text { The demand of gold will keep on increasing } \\
\text { magnanimously due to dynamic population growth, } \\
\text { rapid income growth, strong cultural values and } \\
\text { religious affinity to gold. }\end{array}$ \\
\hline 4 & 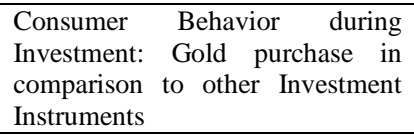 & Jaana Lisette Lutter & 2008 & $\begin{array}{l}\text { Gold is already known and valued by the people for } \\
\text { its stable nature and long tradition }\end{array}$ \\
\hline 5 & $\begin{array}{l}\text { Personality Type and Investment } \\
\text { choice: An empirical Study }\end{array}$ & Manish Mittal & 2008 & $\begin{array}{l}\text { Classified Indian investors into four dominant } \\
\text { investment personalities - casual, technical, } \\
\text { informed and cautious. }\end{array}$ \\
\hline 6 & $\begin{array}{l}\text { Is gold a safe haven? International } \\
\text { evidence. }\end{array}$ & $\begin{array}{l}\text { Dirk G.Baur, Thomas } \\
\text { K \& Mc Dermott }\end{array}$ & 2010 & $\begin{array}{l}\text { Gold represents a safe haven against stocks of } \\
\text { major emerging and developing countries. }\end{array}$ \\
\hline 7 & $\begin{array}{l}\text { Is Gold a Hedge or a Safe Haven? } \\
\text { An Analysis of Stocks, Bonds and } \\
\text { Gold }\end{array}$ & $\begin{array}{lll}\text { Dirk G Baur \& } \\
\text { B.M.Lucey }\end{array}$ & 2010 & $\begin{array}{l}\text { Investors buy gold on days of extreme negative } \\
\text { returns and sell it when market participants regain } \\
\text { confidence and volatility is lower. }\end{array}$ \\
\hline 8 & $\begin{array}{l}\text { Factors Influencing Gold } \\
\text { Consumption for Savings and } \\
\text { Investments by People in the } \\
\text { Bangkok Metropolitan Area. }\end{array}$ & $\begin{array}{l}\text { Kulkanya Napompech } \\
\text { et al. }\end{array}$ & 2010 & $\begin{array}{l}\text { The sample group attached the most importance to } \\
\text { the factor of the faulty economy and political, } \\
\text { fluctuating oil prices, as well as lesser interest rate } \\
\text { of bank deposits for preferring gold as an } \\
\text { investment. }\end{array}$ \\
\hline
\end{tabular}




\begin{tabular}{|c|c|c|c|c|}
\hline 9 & $\begin{array}{l}\text { Do Men and Women accumulate } \\
\text { assets in different ways, Evidence } \\
\text { from Rural Bangladesh }\end{array}$ & Agnes R.Quisumbing & 2011 & $\begin{array}{l}\text { Factors that affect husbands' and wives' ability to } \\
\text { form social and familial networks also affect asset } \\
\text { accumulation }\end{array}$ \\
\hline 10 & $\begin{array}{l}\text { Do households Still Prefer Bank } \\
\text { Deposits? An Analysis of Shift in } \\
\text { Savings and Savings Determinants }\end{array}$ & A.P. Pati and D.Shome & 2011 & $\begin{array}{l}\text { Households are preferring the safe channels of } \\
\text { bank deposit schemes rather than switching over to } \\
\text { high yielding but risky channels of savings }\end{array}$ \\
\hline 11 & $\begin{array}{l}\text { Gold ETFs: An Emerging } \\
\text { Investment Option. }\end{array}$ & $\begin{array}{l}\text { Prashanta Athma \& } \\
\text { Suchitra K. }\end{array}$ & 2011 & $\begin{array}{l}\text { Gold ETFs is an emerging option of the various } \\
\text { investment alternatives available to the investor but } \\
\text { its investment is low due to less awareness among } \\
\text { the investors and the sentimental attachment of the } \\
\text { investors towards holding gold in the physical } \\
\text { form. }\end{array}$ \\
\hline 12 & $\begin{array}{l}\text { Investment Habits among the } \\
\text { Households. }\end{array}$ & Sanjay Kanthi Das & 2011 & $\begin{array}{l}\text { Household Savings in the physical properties were } \\
\text { weighted more than household savings in the } \\
\text { financial instruments }\end{array}$ \\
\hline 13 & $\begin{array}{l}\text { A Review on Gold Quest in the } \\
\text { Investment Portfolio } \\
\text { by Indian Investors }\end{array}$ & Anli Suresh & 2011 & $\begin{array}{l}\text { Gold is a major vehicle of saving for large number } \\
\text { of low and middle income households in rural and } \\
\text { urban areas. }\end{array}$ \\
\hline 14 & $\begin{array}{l}\text { Gold vs. Stock Investment: An } \\
\text { Econometric Analysis. }\end{array}$ & $\begin{array}{l}\text { Martin Surya Mulyadi } \\
\& \text { Yunita Anwar }\end{array}$ & 2012 & $\begin{array}{l}\text { Gold as a good portfolio diversifier and a hedge } \\
\text { against stocks as well as a safe haven in extreme } \\
\text { stock market conditions. }\end{array}$ \\
\hline 15 & $\begin{array}{l}\text { A Study On Investment Behavior } \\
\text { of Professors Towards Gold with } \\
\text { Special Reference to Tamil Nadu } \\
\text { State. }\end{array}$ & P.Arulmurugan et al. & 2013 & $\begin{array}{l}\text { Future Prospects, Risk Management, Ideal Time } \\
\text { for investment, Conventional Value and } \\
\text { Alternative Investment tool were categorized as } \\
\text { major variables under Factor Analysis. }\end{array}$ \\
\hline 16 & $\begin{array}{l}\text { Gold vs. Stock Market: A } \\
\text { Comparative Study of Risk and } \\
\text { Return }\end{array}$ & $\begin{array}{l}\text { Barinder Singh \& } \\
\text { J.B.Nadda }\end{array}$ & 2013 & $\begin{array}{l}\text { Investment at any point of time in gold will yield } \\
\text { some positive returns, so it is not risky for an } \\
\text { investor while it is very tough task for an individual } \\
\text { to invest in stocks until and unless he possesses } \\
\text { technical knowledge involved with it. }\end{array}$ \\
\hline 17 & $\begin{array}{l}\text { A Study on Preferred Investment } \\
\text { Avenues among Salaried Peoples } \\
\text { with Reference to Namakkal } \\
\text { Taluk, Tamil Nadu, India. }\end{array}$ & $\begin{array}{l}\text { V.R.Palanivelu } \\
\text { K.Chandrakumar }\end{array}$ & 2013 & $\begin{array}{l}\text { Factors like education level, awareness about the } \\
\text { current financial system, age of investors etc make } \\
\text { significant impact while deciding the investment } \\
\text { avenues. }\end{array}$ \\
\hline 18 & $\begin{array}{l}\text { Influence of Lifestyle Perception } \\
\text { on Gold Purchase Decisions }\end{array}$ & $\begin{array}{l}\text { V.Sujatha } \\
\text { S.Kumaresan }\end{array}$ & 2013 & $\begin{array}{l}\text { Gold was considered a formidable part of } \\
\text { showcasing the Indian customs and there was a } \\
\text { significant influence of gender on gold buying } \\
\text { behavior. }\end{array}$ \\
\hline
\end{tabular}

Table 2: Factor Scores and Communalities

\begin{tabular}{|c|c|c|c|c|c|c|c|c|c|c|c|}
\hline & F1 & F2 & F3 & F4 & F5 & F6 & F7 & F8 & F9 & F10 & Communality \\
\hline VAR1 & 0.108 & 0.032 & 0.096 & 0.001 & 0.781 & 0.112 & 0.136 & 0.231 & 0.025 & -0.033 & 0.718 \\
\hline VAR2 & 0.09 & 0.115 & 0.062 & 0.126 & 0.829 & -0.215 & 0.001 & -0.078 & -0.091 & -0.004 & 0.788 \\
\hline VAR3 & $\mathbf{0 . 8 3 4}$ & -0.02 & 0.104 & -0.038 & 0.174 & 0.056 & -0.060 & 0.050 & 0.036 & 0.086 & 0.756 \\
\hline VAR4 & 0.435 & 0.119 & -0.128 & 0.172 & 0.130 & 0.501 & 0.333 & 0.206 & 0.183 & 0.135 & 0.723 \\
\hline VAR5 & -0.116 & 0.398 & -0.107 & 0.230 & -0.006 & 0.111 & -0.438 & 0.509 & -0.018 & 0.102 & 0.710 \\
\hline VAR6 & 0.124 & -0.030 & 0.391 & 0.414 & 0.042 & 0.076 & 0.156 & 0.271 & -0.141 & -0.214 & 0.512 \\
\hline VAR7 & 0.326 & 0.048 & 0.682 & 0.072 & -0.003 & -0.045 & -0.097 & 0.383 & 0.096 & -0.163 & 0.773 \\
\hline VAR8 & 0.508 & -0.149 & 0.268 & 0.094 & -0.148 & -0.200 & 0.038 & 0.384 & 0.177 & 0.136 & 0.623 \\
\hline VAR9 & 0.06 & 0.056 & 0.711 & 0.110 & 0.173 & 0.146 & 0.061 & 0.007 & 0.075 & 0.156 & 0.609 \\
\hline VAR10 & 0.285 & 0.192 & 0.283 & 0.090 & -0.033 & 0.022 & 0.092 & 0.172 & 0.587 & -0.307 & 0.684 \\
\hline VAR11 & -0.054 & 0.130 & 0.100 & 0.091 & -0.054 & -0.027 & 0.014 & -0.043 & 0.796 & 0.181 & 0.710 \\
\hline VAR12 & 0.070 & -0.019 & 0.063 & 0.677 & 0.018 & 0.143 & -0.142 & -0.137 & 0.159 & -0.007 & 0.553 \\
\hline VAR13 & -0.058 & 0.125 & 0.005 & 0.766 & 0.063 & -0.031 & -0.125 & 0.167 & 0.049 & 0.086 & 0.664 \\
\hline VAR14 & 0.308 & 0.273 & 0.290 & 0.551 & 0.156 & 0.016 & 0.199 & -0.166 & -0.187 & 0.070 & 0.689 \\
\hline VAR15 & 0.011 & -0.07 & 0.515 & 0.315 & 0.090 & -0.160 & -0.100 & -0.316 & 0.262 & 0.117 & 0.595 \\
\hline VAR16 & -0.141 & $\mathbf{0 . 4 5 1}$ & 0.256 & 0.223 & 0.280 & 0.177 & 0.033 & 0.106 & 0.232 & 0.096 & 0.524 \\
\hline VAR17 & -0.048 & 0.077 & 0.058 & 0.063 & 0.633 & 0.410 & 0.043 & 0.056 & -0.027 & 0.295 & 0.677 \\
\hline VAR18 & 0.209 & 0.116 & 0.059 & 0.083 & 0.148 & 0.105 & 0.055 & 0.119 & 0.040 & 0.783 & 0.732 \\
\hline VAR19 & 0.511 & 0.070 & 0.475 & 0.097 & -0.100 & 0.085 & 0.107 & -0.109 & 0.174 & 0.073 & 0.578 \\
\hline VAR20 & -0.027 & 0.327 & 0.373 & 0.022 & 0.296 & 0.306 & 0.306 & -0.352 & -0.112 & 0.182 & 0.692 \\
\hline VAR21 & -0.074 & 0.220 & -0.196 & 0.122 & 0.257 & -0.207 & 0.688 & -0.101 & 0.091 & -0.065 & 0.712 \\
\hline VAR22 & 0.041 & 0.740 & -0.204 & 0.050 & 0.234 & 0.099 & -0.167 & -0.105 & 0.189 & $\begin{array}{l}-0.12 \\
\end{array}$ & 0.747 \\
\hline VAR23 & 0.342 & 0.148 & 0.390 & -0.049 & 0.321 & -0.105 & -0.049 & 0.099 & 0.266 & 0.28 & 0.569 \\
\hline VAR24 & -0.138 & 0.641 & 0.179 & -0.092 & 0.041 & 0.145 & 0.275 & 0.220 & -0.060 & 0.142 & 0.641 \\
\hline VAR25 & -0.158 & 0.448 & 0.263 & 0.122 & -0.137 & -0.047 & 0.099 & -0.081 & 0.175 & 0.475 & 0.604 \\
\hline VAR26 & -0.098 & 0.491 & 0.165 & 0.176 & -0.131 & -0.175 & 0.408 & -0.179 & -0.211 & 0.169 & 0.628 \\
\hline VAR27 & -0.013 & 0.029 & 0.127 & -0.233 & -0.004 & 0.213 & 0.685 & 0.016 & 0.017 & 0.101 & 0.598 \\
\hline VAR28 & 0.827 & -0.066 & 0.048 & -0.096 & 0.042 & 0.110 & -0.066 & 0.000 & -0.108 & -0.042 & 0.732 \\
\hline
\end{tabular}


Herd Behaviour and Gold Investment: A Perceptual Study of Retail Investors

\begin{tabular}{|l|l|l|l|l|l|l|l|l|l|l|l|} 
VAR29 & 0.061 & 0.125 & 0.105 & 0.087 & -0.091 & $\mathbf{0 . 7 8 5}$ & -0.154 & 0.038 & -0.114 & -0.084 & 0.708 \\
\hline VAR30 & -0.313 & 0.043 & 0.172 & 0.687 & 0.024 & 0.262 & 0.100 & 0.146 & 0.063 & 0.086 & 0.713 \\
\hline VAR31 & 0.179 & 0.637 & 0.004 & 0.095 & 0.050 & 0.299 & 0.116 & 0.120 & 0.206 & 0.131 & 0.627 \\
\hline VAR32 & 0.062 & 0.270 & -0.009 & 0.239 & 0.183 & $\mathbf{0 . 6 3 6}$ & 0.204 & 0.148 & 0.092 & 0.181 & 0.676 \\
\hline VAR33 & 0.083 & 0.050 & 0.082 & 0.034 & 0.216 & 0.173 & -0.040 & $\mathbf{0 . 7 5 0}$ & 0.019 & 0.083 & 0.666 \\
\hline $\begin{array}{l}\text { Eigen } \\
\text { Values }\end{array}$ & 5.981 & 3.236 & 2.385 & 2.271 & 1.842 & 1.579 & 1.300 & 1.197 & 1.080 & 1.063 & - \\
\hline $\begin{array}{l}\text { Cumulative } \\
\begin{array}{l}\text { Percentage } \\
\text { of Variance }\end{array}\end{array}$ & 18.124 & 27.929 & 35.156 & 42.036 & 47.618 & 52.403 & 56.342 & 59.971 & 63.243 & 66.465 & - \\
\hline
\end{tabular}

(Source: SPSS 17); Bold Values indicate highest factor scores.

Table 3: Factor Naming

\begin{tabular}{|c|c|c|c|}
\hline $\begin{array}{l}\text { Factor } \\
\text { Number }\end{array}$ & $\begin{array}{l}\text { Factor name \& Variance } \\
\text { explained }\end{array}$ & Variables Included in the Factor & $\begin{array}{l}\text { Factor } \\
\text { Loading }\end{array}$ \\
\hline \multirow[t]{4}{*}{ F1 } & Profitability (18.124\%) & $\begin{array}{l}\text { I have a keen interest in investment that yields greater } \\
\text { returns. }\end{array}$ & 0.834 \\
\hline & & $\begin{array}{l}\text { One needs to invest to earn return on your surplus } \\
\text { resources. }\end{array}$ & 0.827 \\
\hline & & $\begin{array}{l}\text { I heard that Gold prices will go up, so I will invest in } \\
\text { Gold. }\end{array}$ & 0.511 \\
\hline & & $\begin{array}{l}\text { Gold has always given high returns over a long period, } \\
\text { that's why it's preferable. }\end{array}$ & 0.508 \\
\hline \multirow[t]{4}{*}{$\mathrm{F} 2$} & Safety $(9.805 \%)$ & $\begin{array}{l}\text { I view gold as an investment vehicle which provides } \\
\text { some measure of financial security for me and/or my } \\
\text { children. }\end{array}$ & 0.740 \\
\hline & & $\begin{array}{l}\text { Physical Holding of gold is much better than Traded } \\
\text { Gold. }\end{array}$ & 0.641 \\
\hline & & $\begin{array}{l}\text { Buying gold bars and coins is the safest mode of } \\
\text { investment. }\end{array}$ & 0.637 \\
\hline & & $\begin{array}{l}\text { I usually buy BIS Certified Hallmark gold as it has } \\
\text { purity certification. }\end{array}$ & 0.491 \\
\hline \multirow[t]{3}{*}{$\mathrm{F} 3$} & Time Value of Money $(7.227 \%)$ & $\begin{array}{l}\text { The value of gold has not decreased since past, so it } \\
\text { would prove beneficial. }\end{array}$ & 0.711 \\
\hline & & $\begin{array}{l}\text { Growth on investment in gold is comparatively much } \\
\text { higher. }\end{array}$ & 0.682 \\
\hline & & $\begin{array}{l}\text { Buying Gold as an investment is a win-win situation in } \\
\text { present economy. }\end{array}$ & 0.515 \\
\hline \multirow[t]{4}{*}{ F4 } & Conventional Value & Gold is a status symbol. & 0.766 \\
\hline & $(6.881 \%)$ & $\begin{array}{l}\text { Gold has an ornamental value, which other } \\
\text { investments don't have. }\end{array}$ & 0.687 \\
\hline & & I buy gold for special occasions. & 0.677 \\
\hline & & $\begin{array}{l}\text { I will buy gold for giving it to my children on their } \\
\text { marriages. }\end{array}$ & 0.551 \\
\hline \multirow[t]{3}{*}{ F5 } & Traditional Value $(5.582 \%)$ & Gold possession is significantly valued in our culture. & 0.829 \\
\hline & & $\begin{array}{l}\text { My mother invests in Gold, so I prefer buying gold as } \\
\text { an investment. }\end{array}$ & 0.781 \\
\hline & & Purchasing Gold is a societal ritual. & 0.633 \\
\hline \multirow[t]{3}{*}{ F6 } & Ideal Investment Tool $(4.785 \%)$ & $\begin{array}{l}\text { It is easy to get loan from banks since gold is accepted } \\
\text { as a bank security. }\end{array}$ & 0.785 \\
\hline & & $\begin{array}{l}\text { It can be instantly exchanged in any currency around } \\
\text { the world. }\end{array}$ & 0.636 \\
\hline & & $\begin{array}{l}\text { I can't deposit my money in banks so it's best to invest } \\
\text { in gold. }\end{array}$ & 0.501 \\
\hline \multirow[t]{2}{*}{ F7 } & Future Prospect & Gold is an asset for coming times. & 0.688 \\
\hline & $(3.939 \%)$ & Gold has proper Resale Value. & 0.685 \\
\hline \multirow[t]{2}{*}{ F8 } & Tax Aversion (3.629\%) & $\begin{array}{l}\text { Since there is no regular income from investment in } \\
\text { gold, the income will not be subjected to tax. }\end{array}$ & 0.750 \\
\hline & & $\begin{array}{l}\text { We need not show gold investments in our IT returns } \\
\text { so it's a good avenue. }\end{array}$ & 0.509 \\
\hline \multirow[t]{2}{*}{ F9 } & Risk Management (3.273\%) & $\begin{array}{l}\text { The risk of losing money by investing in gold is lower } \\
\text { than other investments. }\end{array}$ & 0.796 \\
\hline & & $\begin{array}{l}\text { We can sell a part of gold to meet our urgent needs at } \\
\text { the time of crisis. }\end{array}$ & 0.587 \\
\hline \multirow[t]{2}{*}{$\mathrm{F} 10$} & Trustworthiness $(3.222 \%)$ & $\begin{array}{l}\text { I cannot afford buying Gold but I know it's a healthy } \\
\text { investment. }\end{array}$ & 0.783 \\
\hline & & Gold bought at any time will prove beneficial. & 0.475 \\
\hline
\end{tabular}

